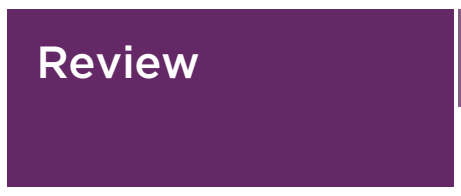

\title{
The islet ghrelin cell
}

\section{Nils Wierup, Frank Sundler and R Scott Heller ${ }^{1}$}

Unit of Neuroendocrine Cell Biology, Department of Clinical Sciences in Malmö, Lund University Diabetes Centre, Clinical Research Centre, Scania University Hospital, Jan Waldenströms gata 35, SE 20502 Malmö, Sweden ${ }^{1}$ Imaging Team, Novo Nordisk A/S, Novo Nordisk Park, DK2760 Måløv, Denmark
Correspondence should be addressed to $\mathrm{N}$ Wierup

Email

nils.wierup@med.lu.se

\begin{abstract}
The islets of Langerhans are key regulators of glucose homeostasis and have been known as a structure for almost one and a half centuries. During the twentieth century several different cell types were described in the islets of different species and at different developmental stages. Six cell types with identified hormonal product have been described so far by the use of histochemical staining methods, transmission electron microscopy, and immunohistochemistry. Thus, glucagon-producing $\alpha$-cells, insulin-producing $\beta$-cells, somatostatin-producing $\delta$-cells, pancreatic polypeptide-producing PP-cells, serotoninproducing enterochromaffin-cells, and gastrin-producing G-cells have all been found in the mammalian pancreas at least at some developmental stage. Species differences are at hand and age-related differences are also to be considered. Eleven years ago a novel cell type, the ghrelin cell, was discovered in the human islets. Subsequent studies have shown the presence of islet ghrelin cells in several animals, including mouse, rat, gerbils, and fish. The developmental regulation of ghrelin cells in the islets of mice has gained a lot of interest and several studies have added important pieces to the puzzle of molecular mechanisms and the genetic regulation that lead to differentiation into mature ghrelin cells. A body of evidence has shown that ghrelin is an insulinostatic hormone, and the potential for blockade of ghrelin signalling as a therapeutic avenue for type 2 diabetes is intriguing. Furthermore, ghrelin-expressing pancreatic tumours have been reported and ghrelin needs to be taken into account when diagnosing pancreatic tumours. In this review article, we summarise the knowledge about islet ghrelin cells obtained so far.
\end{abstract}
Key Words
- ghrelin
- islet
- ghrelin cell
- pancreas
- human
- rat
- mouse
- diabetes
- development

Journal of Molecular Endocrinology (2014) 52, R35-R49

\section{Introduction}

The pancreatic islets were first described by Langerhans (1869). He noticed clusters of cells, 100-200 $\mu \mathrm{m}$ in diameter, that were interspersed in the exocrine tissue. He named these clusters Zellhaufen. Langerhans also described that these clusters were more richly innervated than the surrounding pancreatic tissue.

In 1893, Laguesse proposed the name 'islets of Langerhans' in honour of their discoverer (Biedl (1913); for review see Laguesse (1893) and Falkmer (1995)). During the almost one and a half centuries that have passed since the islets were first discovered, several islet cell types have been described in different mammalian species and at different stages of development. In adult humans, the islets have until recently been thought to harbour four endocrine cell types characterised by respect to their principal hormone content, i.e. the insulin-producing $\beta$-cells, the glucagon-producing $\alpha$-cells, the somatostatinproducing $\delta$-cells and the pancreatic polypeptideproducing PP-cells. This concept was based on the findings made during the twentieth century using mainly three

Published by Bioscientifica Ltd 
different approaches, i.e. histochemical staining methods, transmission electron microscopy and immunohistochemistry. Evidence for the existence of a novel islet cell type, the islet ghrelin cell, has been presented and confirmed by several laboratories. This cell is the fifth cell type to be described in the adult human islets. Further, it is the seventh islet cell with known hormonal content when counting all mammalian species and all developmental stages. Species differences with respect to islet ghrelin cells occur and, further complicating studies of the role of ghrelin cells in islets, the ghrelin cells display a developmental regulation. This review aims at summarising what is known so far about ghrelin cells in the islets of different species and at different developmental stages.

\section{Discovery of the islet cell types}

\section{$\beta$-cells}

Based on studies showing that islet cells harboured granules distinct from the exocrine zymogen granules, Lane demonstrated in 1907 that the islets contain at least two different cell types (Lane 1907). He showed that the granules displayed different properties in different cells and that the cells we now know as $\beta$-cells stained basophilic with certain staining methods, while the other cells did not (Samols 1991). The non-B-cells were called A-cells. The principal hormone, insulin, of the B-cells was discovered by Banting \& Best (1922). Later immunohistochemical studies provided evidence for insulin as the hormonal content of the B-cells (Lacy \& Davies 1957). The B-cell was ultrastructurally characterised by several groups; e.g. Lacy (1957) described the B-cell ultrastructure in several mammals and Like (1967) made a corresponding description of B-cells of normal human pancreas. The granules of the B-cells are characterised by a dense core of crystalline structure in humans and round to ovoid in rodents, surrounded by an electron lucent halo between the membrane and the core.

\section{$\alpha$-cells}

Several decades after the studies by Lane, it became evident that the A-cells, defined as non-B-cells, were in fact two cell populations; one that was argyrophil, the A1 cells, and another that was not argyrophil, the A2-cells, with the contemporary silver stainings (Hellman et al. 1962). Later the $\alpha$-cells (A2) could be specifically distinguished from the other cells by virtue of their argyrophilia using, e.g. the Grimelius (1968) silver impregnation technique. Based on the finding that the ventral part of pancreas is poorly supplied with A-cells and also virtually lacking glucagon in dogs and cats, the work of Bencosme \& Liepa (1955) and Bencosme et al. (1955) provided indirect evidence that glucagon is the hormonal product of A-cells. This notion was confirmed in 1962 when Baum et al. (1962) and Mikami \& Ono (1962) showed by the use of immunohistochemical techniques that the A-cells store glucagon. As for the B-cells, the ultrastructure of the A-cells was described by several groups (Lacy 1957, Like 1967, Sundler \& Håkanson 1988). The A-cells is characterised by highly electron dense, uniformly sized and spherical dense cores of the granules. Further, the granule membrane is separated from the dense cores by a distinct but narrow electron lucent halo.

\section{$\delta$-cells}

The third cell type, the cells we now know as the $\delta$-cells were originally described by Bloom (1931). He described a cell type, which he named the D-cell, that stained differently than the A and B-cells described by Lane, when using the Mallory-azan staining (Bloom 1931). It needs to be mentioned here that a C-cell was described earlier by Bensley; this cell lacks granules and has later been regarded as non-endocrine cell (Bloom 1931). Probably, this was the reason for Bloom to name the cell D-cell, instead of C-cell, which would have caused a more streamlined nomenclature for the islet cells when looking in retrospect. More than 30 years after the initial studies by Bloom, the $\delta$-cells were rediscovered as a subpopulation of the A-cells, the so-called A1-cells, when it became evident that they could be identified for their argyrophilia using a novel silver impregnation method, the Hellerström-Hellman silver method (Hellerström \& Hellman 1960, 1962, Hellman et al. 1962). Fujita (1968) proposed that the D-cells described by Bloom were actually identical to the (A1) cell described by Hellerstöm \& Hellman. Efforts of several laboratories, and the use of immunocytochemistry for somatostatin led to the discovery of the hormonal content of the $\delta$-cell (Hokfelt et al. 1975, Orci et al. 1975, Polak et al. 1975, Alumets et al. 1977). The $\delta$-cells are ultrastructurally characterised by round fairly electron lucent granules (Alumets et al. 1977, Sundler \& Håkanson 1988).

\section{PP-cells}

The fourth islet cell type, the PP-cell, was discovered using immunocytochemistry in 1974: first in chicken

Published by Bioscientifica Ltd 
(Larsson et al. 1974), thereafter in humans in 1975 (Larsson et al. 1975) and in several mammals in 1976 (Larsson et al. 1976b). PP turned out to be the hormonal content of one population of the cells with small granules that had been identified with electron microscopy earlier (Ekblad \& Sundler 2002). In rats, the PP-cells are recognised by their small moderately electron dense granules that are distinguishable from those of other small granular cells due to their irregular shape (Larsson et al. 1976a). In cats and dogs, the PP-cells turned out to be identical to the previously described F-cells (Ekblad \& Sundler 2002). Further adding to the complexity, PP-cells in human pancreas seem to be of two types: one small-granular and the other one with large granules, reminiscent of feline and canine PP-cells (Solcia et al. 1985, Sundler \& Håkanson 1988, Ekblad \& Sundler 2002).

\section{Enterochromaffin-cells and G-cells}

In addition, less frequently occurring, sometimes transiently present during embryonic development and species-specific islet cell types have been described. Thus, serotonin-producing enterochromaffin (EC)-cells, thought to correspond to the EC-cells of the gut, are regularly seen dispersed in the pancreas in certain species, e.g. the pig (Capella et al. 1978, Alumets et al. 1983) and gastrinproducing G-cells have been demonstrated in the rat pancreas during neonatal development, while such cells are present, albeit in small numbers, in the pancreas of adult cat and dog (Larsson et al. 1976a). Recently, G-cells have also been found to be a distinct islet cell type in mice during development (Suissa et al. 2013).

\section{Morphologically characterised cells without known hormonal content}

A few less well-defined cell types have been described in the islets in different species and at different stages of ontogenetic development. Hence, cells with small granules, such as the P-cell (Capella et al. 1978) and the D1-cell (Larsson et al. 1976b), collectively referred to as P/D1-cells (Rindi et al. 2002a), are present in the human islets. One report also described small granule cells in human pancreas as type VI cells (Jirasek \& Kubes 1972). These cells were all characterised merely with respect to ultrastructure and the hormone product has remained unknown for more than three decades (Larsson et al. 1976b, Capella et al. 1978, Bordi et al. 1986, Solcia et al. 1987, Sundler \& Håkanson 1988).

\section{The novel hormone ghrelin}

In their search for an endogenous ligand of the previously characterised orphan growth hormone secretagogue receptor (GHS-R; Howard et al. 1996), Kojima et al. (1999) isolated a novel 28 amino acid peptide from rat stomach, which activated GHS-R signalling in a cell line transfected with GHS-R1a. The peptide was given the name ghrelin, for its ability to stimulate growth hormone (GH) secretion (GH-relin). Independently, searching for genes with expression restricted to the gastric epithelium, Tomasetto et al. (2000) discovered an mRNA in the mouse stomach, which encodes a novel protein of 117 amino acid residues with distant chemical relationship to the motilin precursor; due to its resemblance with prepromotilin it was named motilin-related peptide (MTLRP). It was soon acknowledged that MTLRP is, in fact, the mouse homologue of preproghrelin (Peeters 2005). Kojima et al. (1999) found a difference between postulated and actual molecular weight of ghrelin. The explanation for this turned out to be a previously unknown posttranslational modification, the octanoylation of the $\mathrm{N}$-terminally third serine residue. This octanoylation has been claimed to be essential for the biological activity of ghrelin. Other forms of ghrelin, including nonoctanoylated ghrelin as well as a variant lacking one amino acid, have been reported as reviewed in Korbonits et al. (2004).

\section{Sources of circulating ghrelin}

The initial studies by Kojima et al. (1999) and Tomasetto et al. (2000) localised ghrelin to the stomach. Later studies showed that the gastric source of ghrelin was the previously ultrastructurally characterised and 'hormoneless' A-like cells in rats and the P/D1-cells in humans (Date et al. 2000, Dornonville de la Cour et al. 2001, Rindi et al. 2002a). Predominantly in rodents, gut ghrelin cells are most abundant in the oxyntic mucosa, less frequent in the gastric antrum and still fewer in the small intestine (Date et al. 2000, Dornonville de la Cour et al. 2001). As the stomach is the richest source of ghrelin in adults, other sources of the hormone have been given less attention. Studies on the rat have given much attention to the gastric fundus and ruled out the production of ghrelin from other sites. Thus, in rats only $20 \%$ of circulating ghrelin remains after fundectomy (Dornonville de la Cour et al. 2001). The situation is, however, different in humans where $35-45 \%$ remains after total gastrectomy (Ariyasu et al. 2001, Popovic et al. 2005).

Published by Bioscientifica Ltd 
Thus, although the stomach is the major source of circulating ghrelin, other sources such as the pancreas and intestine (Wierup et al. 2007) clearly contribute.

\section{Discovery of the islet ghrelin cell}

\section{Ghrelin cells in humans}

Soon after the discovery of ghrelin, we investigated the possibility of ghrelin expression in the human pancreas using in situ hybridisation (ISH) and immunocytochemistry. We also included foetal specimens as previous studies have shown that many islet peptides are transiently overexpressed during foetal development (Wierup $\&$ Sundler 2008). Immunostainings for ghrelin revealed that ghrelin-immunoreactive cells were found in all the human pancreatic specimens studied. The cells were, in fact, numerous in foetal and neonatal pancreas, while fewer in number in the pancreas of adults. Double- or triple-immunostainings for ghrelin and the four main islet hormones (glucagon, insulin, somatostatin and PP) revealed that the ghrelin-immunoreactive cells were consistently devoid of the hormones produced by the well-characterised islet cell types $(\alpha-, \beta-, \delta$ - and PP-cells) (Wierup et al. 2002; Fig. 1). In situ hybridisation for ghrelin mRNA confirmed the ICC data (Wierup et al. 2002). Thus, in foetal and neonatal specimens numerous cells with labelling for ghrelin mRNA were seen at the islet periphery, whereas in adult islets only a few cells with such labelling were seen (Wierup et al. 2002). Further ISH for ghrelin mRNA and the different islet hormones on consecutive islet sections demonstrated the lack of ghrelin mRNA in, e.g. $\alpha$-cells or $\beta$-cell, and consequently, the lack of insulin or glucagon mRNA in ghrelin cells (Wierup 2005). These data led us to the conclusion that the ghrelinimmunoreactive cells constitute a separate, previously unrecognised, islet cell population. We named this novel cell type simply 'the ghrelin cell'. The cells were usually round or ovoid in shape and sometimes issued cytoplasmic extensions. As a rule, the ghrelin cells were located at the peripheral rim of the islets and sometimes, in foetal and neonatal islets, formed a continuous cell layer embracing the other islet cells. A few ghrelin IR cells were also seen in the duct epithelium or as single, extraislet cells dispersed among exocrine cells. When comparing densities of ghrelin cells in pancreata of different gestational stages and in pancreas from adult humans, we found that the ghrelin cells displayed a characteristic developmental regulation. Thus, in foetal (15-26 weeks of gestation) and neonatal specimens, the
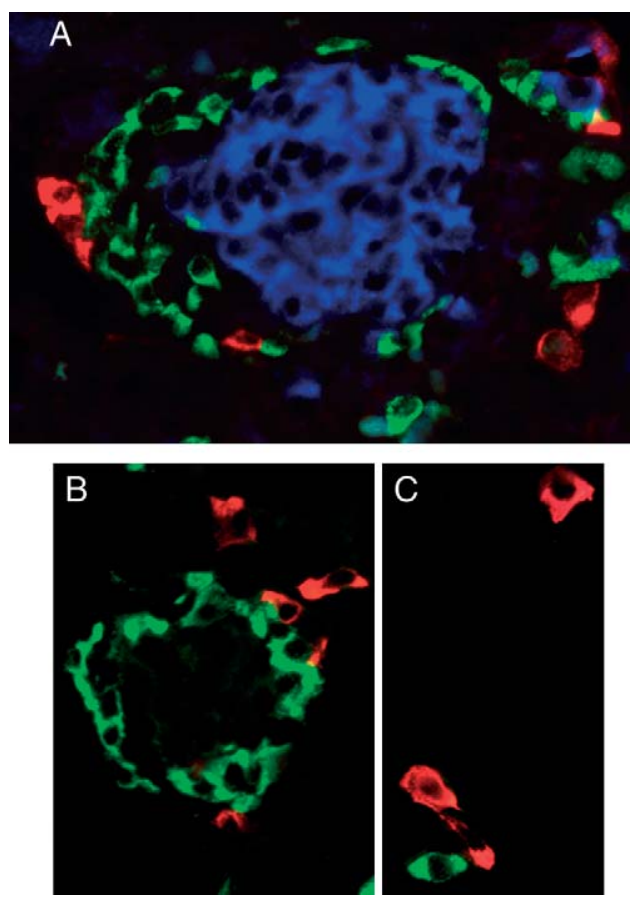

Figure 1

Double- or triple-immunostained foetal human islets (22 weeks of gestation). Ghrelin red in all images. (A) Insulin (blue) and somatostatin (green). (B) Glucagon (green). (C) PP (green). Note that ghrelin is not colocalised with any of the four major islets hormones. For antibody details see Wierup et al. (2002).

ghrelin cells constitute $\sim 10 \%$ of all islet cells; the corresponding figure in adults is $\sim 1 \%$. This developmental pattern of ghrelin-immunoreactive cells in human pancreas was also in part shown by Rindi et al. (2002a). They reported that cells with immunoreactivity for ghrelin were 'fairly represented' in the human foetal pancreas, but were unable to detect ghrelin immunoreactivity in the adult human pancreas. They did not further characterise the ghrelin-immunoreactive cells. A more recent study has showed a similar pattern for ghrelin mRNA (D'Amour et al. 2006). Thus, peak levels of ghrelin mRNA were found at week 14 of gestation, while lower levels was seen in pancreas from adults (D'Amour et al. 2006). The same group also showed, when aiming at producing endocrine cells from human embryonic stem cells, that ghrelin cells appear as a separate cell type distinct from $\alpha-, \beta-, \delta$ - and PP-cells after certain procedures (D'Amour et al. 2006, Kroon et al. 2008). It was also revealed that while many cells expressed more than one islet hormone, e.g. insulin and glucagon, ghrelin was not coexpressed with other islet hormones to the same extent (D'Amour et al. 2006). Our studies in addition showed that there is no difference

Published by Bioscientifica Ltd 
in ghrelin cell density between the head, tail and body of the pancreas. This is different from PP- and $\alpha$-cells. PP-cells predominate in the head-portion, while they are few in the tail portion (Larsson et al. 1976b). The $\alpha$-cells display the opposite distribution, i.e. they are more common in the tail portion than in the head portion (Bencosme \& Liepa 1955).

When ghrelin cell density in foetal pancreas was compared with that in the foetal stomach (the main site of ghrelin production in adults), we found that ghrelin cells were numerous in pancreas, while very few in the stomach. Interestingly, a study of circulating ghrelin in foetal blood showed that the human foetus has endogenous ghrelin production from 20 weeks of gestation to term. This conclusion was based on data showing a lack of correlation between maternal blood levels of ghrelin and foetal blood ghrelin levels, as well as a lack of difference in ghrelin concentration between umbilical vein and artery blood (Cortelazzi et al. 2003). They concluded that the foetus is a source of ghrelin production, and as no other major source was reported, we suggested that ghrelin production in the foetal pancreas is the explanation (Wierup \& Sundler 2004a). Taken together, these data suggest that the pancreas may be the main source of circulating ghrelin during foetal development. These data are supported by similar observations in rodents (Wierup et al. 2004b).

When using transmission electron microscopy and immunogold labelling techniques, it became evident that human ghrelin cells have unique ultrastructural features compared with $\alpha-, \beta-, \delta$ - and PP-cells (Wierup \& Sundler 2005). The ghrelin cell secretory granules are comparatively small and spherical, and the granule cores displayed varying electron density, from dense to rather electronlucent. Further, the limiting membrane is tightly applied to the dense core of most of the granules (Fig. 2). The ghrelin cells are readily distinguished from $\beta$-cells, which are, in the foetus, recognised by the characteristic irregular crystalline dense core of their granules (for references see Klöppel \& Heitz (1984)). Further, ghrelin cells are clearly distinct from $\delta$-cells which are recognised by their large, uniformly electron lucent granules. Ghrelin cells are also readily separated from PP-cells which harbour small and often irregularly shaped, moderately electron dense granules (Sundler \& Håkanson 1988). Nevertheless, although clearly different from those of the other islet cell types, the secretory granules of the ghrelin cells are most similar to those of the $\alpha$-cells; however, careful morphometrical analysis of the diameters of the dense cores of the granules revealed that the ghrelin cells have

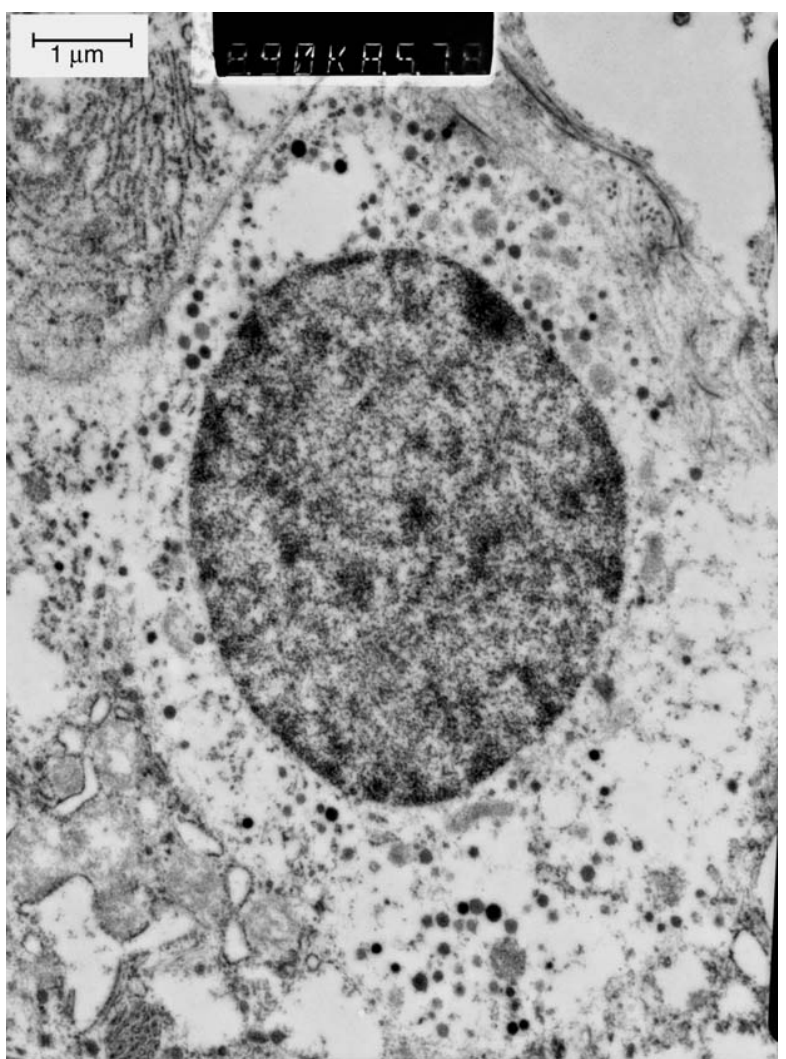

Figure 2

TEM-micrograph of a ghrelin cell in the foetal human pancreas at midgestation. Note that the secretory granules are small, spherical and display varying electron density. For technical details see Wierup \& Sundler (2005).

substantially smaller secretory granules, $(110 \pm 3 \mathrm{~nm})$ than the $\alpha$-cells $(185 \pm 7 \mathrm{~nm})$. Granules of ghrelin cells and the other islet cell types are shown in Fig. 3.

With this knowledge in mind, it became clear that the ghrelin cells shared a lot of features with the previously described, ultrastructurally characterised 'small-granular' islet cell types. Thus, the pattern of developmental regulation (Wierup et al. 2002) and granule properties (Wierup \& Sundler 2005) for ghrelin cells fits well with the previously described 'hormoneless' pancreatic P/D1-cells (Larsson et al. 1976b, Capella et al. 1978, Bordi et al. 1986, Sundler \& Håkanson 1988). Larsson et al. (1976b) described that the granules of D1-cells had fairly low electron density, this is in agreement with our more recent observations for ghrelin cells (Wierup \& Sundler 2005). Capella et al. (1978) reported that P/D1-cells were numerous in the foetal pancreas, but rare in the adult pancreas. They also showed that the cells are numerous in foetal pancreas, while few in the stomach (Capella et al. 1978). This pattern is strikingly similar to that of the

Published by Bioscientifica Ltd 


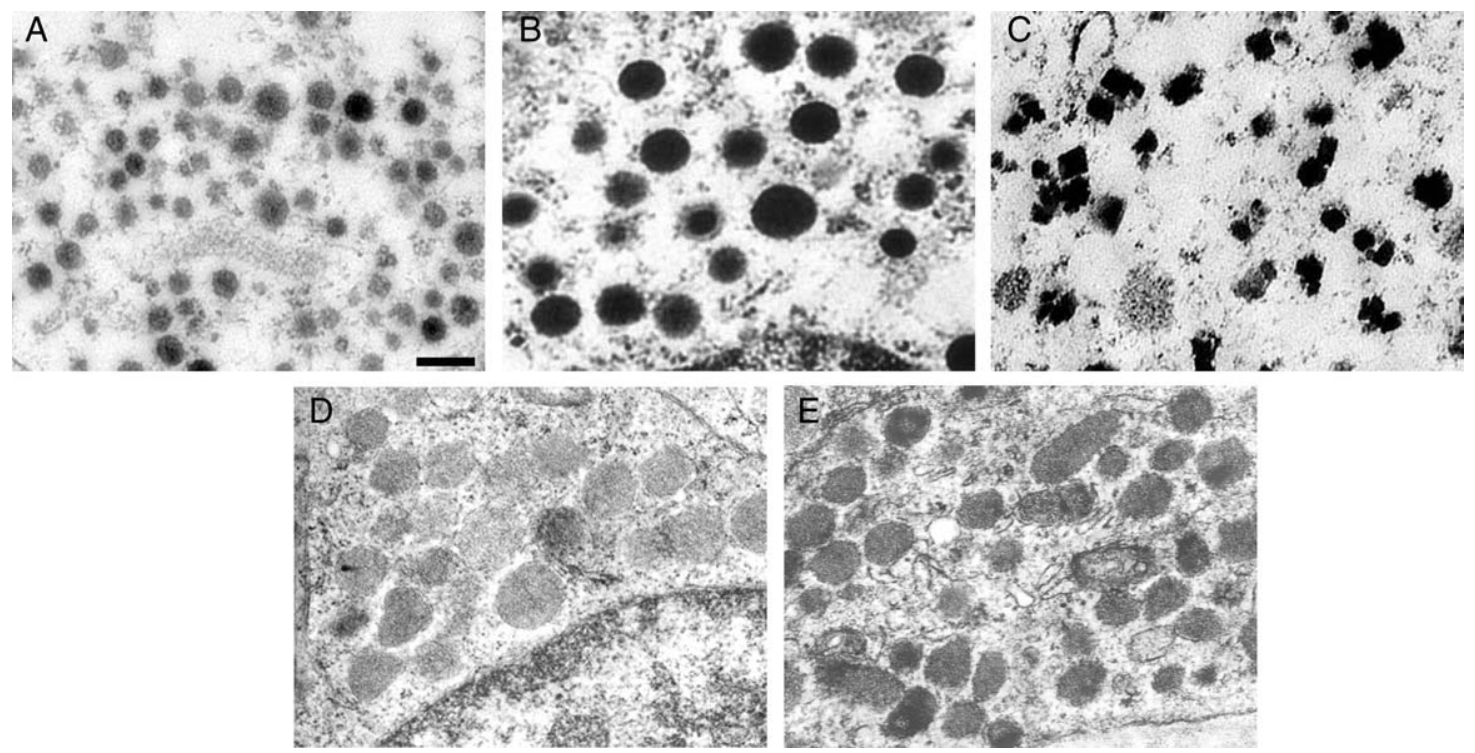

\section{Figure 3}

Transmission electron micrographs of islet cell secretory granules adapted from Wierup \& Sundler (2005). Secretory granules from islet cells. (A) Ghrelin cell. (B) Glucagon cell. (C) Insulin cell. (D) Somatostatin cell.

ghrelin cells (Wierup et al. 2002), suggesting that the islet ghrelin cells in fact are P/D1-cells. Remarkably, Jirasek \& Kubes (1972) described in 1972 a new cell type, the so-called 'type VI cells', in the human islets. They showed that this cell type had granules that were smaller (120-240 nm diameter) than those of D-cells (290-620 nm), and that the type VI-cell was less frequently found than the D-cell, but more frequently found than the pancreatic G-cells (gastrin) and EC-cells. Their data for the type VI cell also fit well with what we today know about ghrelin cells, and we suggest that type VI cells are also in fact identical to ghrelin cells and P/D1-cells. When the P/D1/typeVI-cells were first described with transmission electron microscopy during the seventies, it was not possible to identify the hormonal product, ghrelin, as it was isolated almost 30 years later (Kojima et al. 1999, Tomasetto et al. 2000).

\section{Ghrelin cells in mice}

The development of gene-targeting techniques has favoured the mouse as an animal model for developmental studies. Genetic and transcriptional programming of pancreatic development have gained a lot of interest during the last few decades and studies on mice with disruption of key transcription factors that orchestrate cellular differentiation have provided important information about the molecular events that regulate islet cell
(E) PP-cell. Note that ghrelin cell granules are distinct from other islet cell granules. Scale bar $=250 \mathrm{~nm}$, in A for all images.

fate (reviewed in Edlund (2002) and Oliver-Krasinski \& Stoffers (2008)). When studying mice with a null mutation in the gene for $N k x 2.2$, a homeobox transcription factor expressed in CNS and pancreatic islets (Rudnick et al. 1994), Sussel et al. (1998) found that Nkx2.2 null mutant mice display a large number of islet endocrine cells that are devoid of the four major islet hormones. They also found that the mutant mice develop severe hyperglycaemia, due to lack of $\beta$-cells, and die shortly after birth. Based on normal expression of the $\beta$-cell markers, islet amyloid polypeptide (IAPP) and PDX1 in the mutant islets, they suggested that the unidentified endocrine cell population was incompletely differentiated $\beta$-cells. Later, Prado et al. (2004) showed that these cells were in fact ghrelin cells. Importantly, ghrelin cells were also found to exist in developing islets of normal mice. Independently, Wierup \& Sundler (2004b) and Heller et al. (2005) made similar observations in the mouse. Prado et al. (2004) found that ghrelin cells were present in normal mice from E10.5 and that the density of cells peaked by E15.5. In fact, we have found that ghrelin cells appear already at E8.5 (Fig. 4). On the other hand, only low levels of ghrelin were found in the pancreas of adult mice. In agreement, Wierup \& Sundler (2004b) and Heller et al. (2005) (Wierup N \& Sundler F 2004, Scott-Heller R 2005, unpublished observations) have been unable to find ghrelin cells after 2 weeks of age. Making the story about ghrelin cells in

Published by Bioscientifica Ltd. 

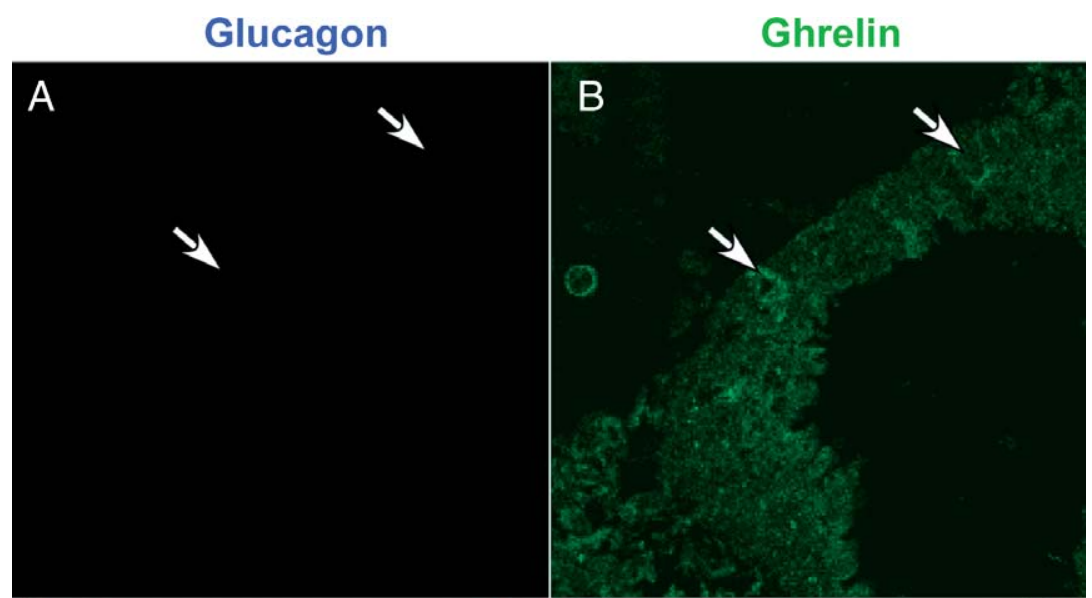

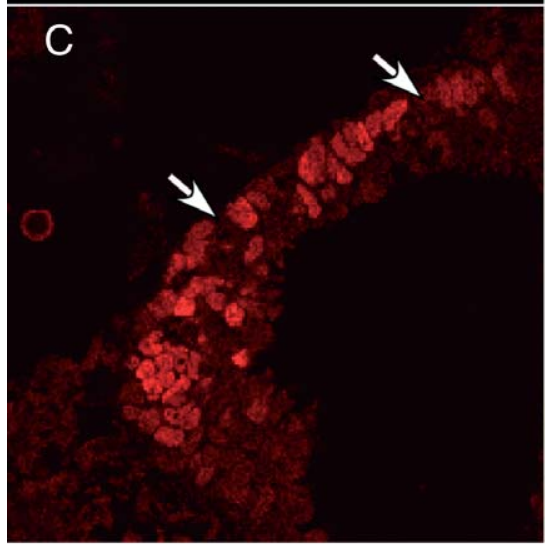

PDX-1

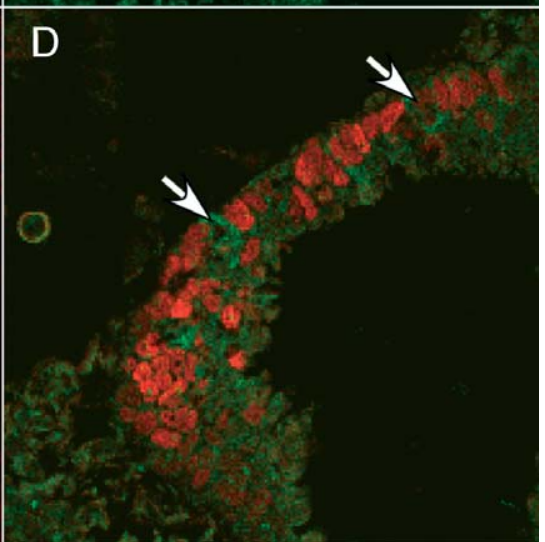

Glu-Ghr- PDX-1

\section{Figure 4}

Expression of glucagon and ghrelin ${ }^{+}$cells at E8.5 in the mouse. The early pancreatic epithelium is localised in red by $\mathrm{Pdx} 1$ immunoreactivity. Two arrows denote cells expressing ghrelin (green) but not

mouse islets more complicated, Prado et al. found in neonatal mice that one-third of the ghrelin IR cells coexpressed glucagon, whereas two-thirds of the ghrelin cells in normal mice constituted a separate cell population. On the other hand, Heller et al. (2005) showed that from E10.5 to P1, 70-95\% of the ghrelin IR cells also express glucagon. Thus, although it is a fact that ghrelin cells constitute a separate cell population in mouse islets, a great proportion of the ghrelin cells harbour glucagon (Prado et al. 2004, Wierup \& Sundler 2004b, Heller et al. 2005). Therefore, in the developing mouse pancreas it is necessary to distinguish between ghrelin ${ }^{+}$glucagon ${ }^{+}$cells and ghrelin ${ }^{+}$glucagon ${ }^{-}$cells. In this respect, the mouse differs from the rat, in which glucagon and ghrelin only occasionally are coexpressed around birth (Wierup et al. $2004 b$ ). It is also different from islet ghrelin cells in humans, in which no glucagon expression has been reported at any stage of development. glucagon (staining absent) at this early developmental time point. For antibody details see Heller et al. (2005). All images are $400 \times$ magnification.

The large degree of coexpression of ghrelin and glucagon observed in the mouse could be interpreted as a relationship with respect to cell lineage between ghrelin cells and $\alpha$-cells. On the other hand, Prado et al. (2004) proposed that ghrelin cells share lineage with the $\beta$-cells, based on the expansion of the ghrelin cell population in the absence of transcription factors crucial for $\beta$-cell development (Prado et al. 2004). Thus, Nkx2.2 mutant mice displayed dramatically increased number of ghrelin ${ }^{+}$ glucagon ${ }^{-}$cells. They also showed that Pax4 mutant mice had an expanded ghrelin cell population, but did not examine whether these cells coexpressed glucagon or not. Interestingly, a subpopulation of the ghrelin ${ }^{+}$cells in WT mice harboured Pax6 (although it is not clear whether these express glucagon or not), and PAX6 protein is absent in Nkx2.2 mutant mice (Heller et al. 2004, Prado et al. 2004). Arx is necessary for the upregulation of ghrelin mRNA levels in $N k x 2.2$ mutant epsilon cells

Published by Bioscientifica Ltd 
(Mastracci et al. 2011) and in addition, Nkx2.2/Arx double mutants result in ghrelin ${ }^{+} /$somatostatin $^{+}$cells, which are never observed in nature. Recent work has clearly demonstrated a very important role for $N k x 2.2$ in repressing the expression of other endocrine hormones in $\beta$-cells, where ghrelin expression cells are formed at the expense of $\beta$-cells in $N k \times 2.2$ knockout mice (Papizan et al. 2011).

On the other hand, Heller et al. (2005) found that neither Pax4 nor the glucagon-cell specific transcription factor Arx (Collombat et al. 2003) impacts on the ghrelin ${ }^{+}$glucagon ${ }^{-}$cell fate. It should be mentioned that Arx null mutant mice had reduced the number of ghrelin $^{+}$glucagon $^{+}$cells, while Pax4 mutants had increased the number of such cells, the latter reminiscent of the findings by Prado et al. (2004). A recent report has confirmed the expansion of the population of ghrelin ${ }^{+}$ glucagon $^{+}$cells in Pax4 deficient mice (Wang et al. 2008). It was, however, not studied how Pax4 deficiency affects the ghrelin ${ }^{+}$glucagon $^{-}$cell population. The same report provided evidence for Arx expression in ghrelin ${ }^{+}$cells. Whether these cells express glucagon or not is not reported. The diminished expression of Pax6 in $N k \times 2.2$ mutant mice is interesting in view of the expanded ghrelin $^{+}$glucagon ${ }^{-}$cell population in these mice. Interestingly, therefore, Heller et al. (2005) showed that the ghrelin ${ }^{+}$glucagon $^{-}$cell population is expanded in Pax6 mutant mice. Furthermore, Pax4 mutant mice, which have a normal ghrelin ${ }^{+}$glucagon $^{-}$cell number, also display normal levels of Pax6 (Wang et al. 2004). The potential for Pax6 as a lineage divider between ghrelin $^{+}$glucagon ${ }^{-}$cells and ghrelin ${ }^{+}$glucagon $^{+}$cells is intriguing and needs further investigation. Notably, ghrelin $^{+}$glucagon $^{-}$cells are devoid of Pax6, whereas ghrelin $^{+}$glucagon $^{+}$cells express Pax6 (Fig. 5). Heller et al. (2005) also found that the ghrelin ${ }^{+}$glucagon $^{-}$cells, like the four major islet cell types, are dependent on the basic helix-loop-helix transcription factor Ngn3 (Gradwohl et al. 2000), because ghrelin-immunoreactive cells are absent in Ngn3 deficient mice during development. Thus it can be concluded that ghrelin cells at least share lineage with all the other four cell types at the early stages of islet cell development. Furthermore, like the majority of all islet cells, ghrelin cells also express Isl1 (Heller et al. 2005). It should be mentioned that, although mice with mutated Foxa2 display 90\% lower glucagon expression than normal mice (Lee et al. 2005), they have a normal number of ghrelin-immunoreactive cells. Whether these cells coexpress glucagon is not known. The transcription factor Brn 4 has been shown to be important for the development of $\alpha$-cells (Hussain et al. 1997). Although Brn4 is seen in subpopulations of the ghrelin cells (Jenny et al. 2004, Wierup \& Sundler 2004b), it does not seem to be essential for ghrelin cell development as Brn4 (Pou3f4) null mutant mice display both scattered ghrelin ${ }^{+}$ glucagon ${ }^{-}$cells and ghrelin ${ }^{+}$glucagon ${ }^{+}$cells (Heller et al . 2004). Finally, mice with a loss of function mutation in microphthalmia transcription factor were recently found to exhibit lower ghrelin mRNA levels (Mazur et al. 2013).

Despite the fact that ghrelin cells are affected by mutations in transcription factors necessary for $\beta$-cell development, it still remains a fact that ghrelin cells in humans, rats and the ghrelin ${ }^{+}$glucagon ${ }^{-}$cells in WT mice do not at any stage of development examined so far express insulin or the $\beta$-cell specific transcription factors PDX1 or Nkx6.1 (Wierup et al. 2002, 2004b, Prado et al. 2004, Wierup \& Sundler 2004b, Heller et al. 2005, Walia et al. 2008). As ghrelin is to a varying extent instead coexpressed with glucagon, PP- and the $\alpha$-cell specific transcription factor Brn4 (Wierup et al. 2004b, Heller et al. 2005, Walia et al. 2008), we rather believe that the ghrelin cells are embryogenetically more closely related to $\alpha$-cells. Very recent work in lineage tracing ghrelin cells during development has demonstrated that they might give rise to a broad range of cell types including $\alpha$, PP cells and rare $\beta$-cells. In addition, the authors observed that a few ghrelin cells are expressed at P0 but are absent during development, and these ghrelin-expressing cells represent a unique Ngn3 independent cell lineage with the ability to become both endocrine as well as duct and exocrine cells (Arnes et al. 2012).

Transmission electron microscopy is the gold standard technique for characterisation of cellular identity. Studies of the ultrastructure of mouse islet ghrelinimmunoreactive cells are, however, lacking. Information about potential differences in ultrastructural properties between ghrelin ${ }^{+}$glucagon ${ }^{+}$cells and ghrelin ${ }^{+}$glucagon ${ }^{-}$ cells would add important pieces to the hitherto unresolved cell lineage puzzle.

\section{Ghrelin cells in rats}

Ghrelin cells are also present in rat pancreas during foetal and neonatal development (Wierup et al. 2004b, Fak et al. 2007, Walia et al. 2008). As in the human (Wierup et al. 2002, Wierup \& Sundler 2005) and mouse (Prado et al. 2004, Heller et al. 2005) pancreas, the rat ghrelin cells display a developmental regulation (Wierup et al. 2004b). Thus, ghrelin cells are readily seen from midgestation to 1 month postnatally, with the density of the cells peaking

Published by Bioscientifica Ltd. 


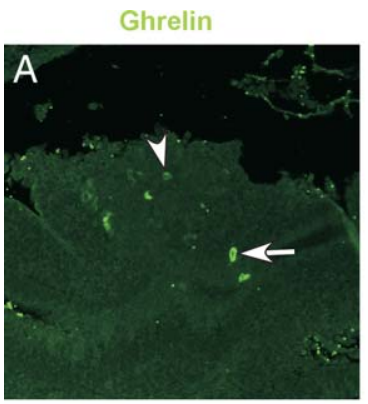

Ghrelin

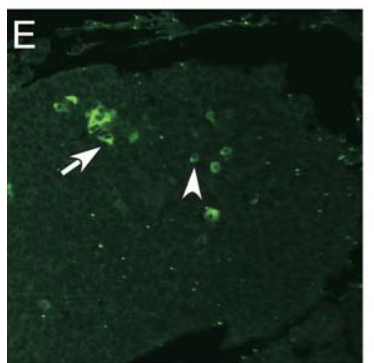

Ghrelin

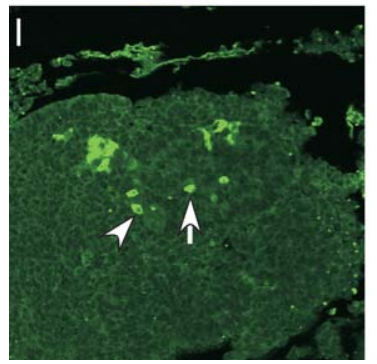

Nkx2.2

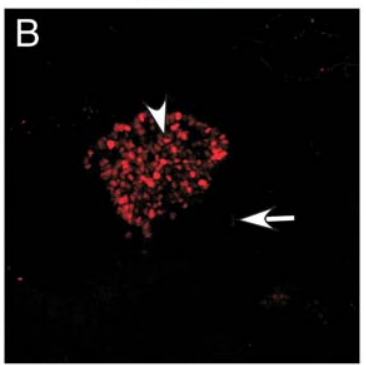

Brn4

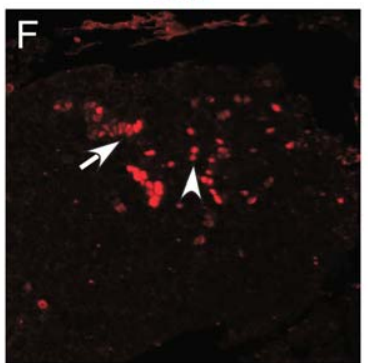

Pax6

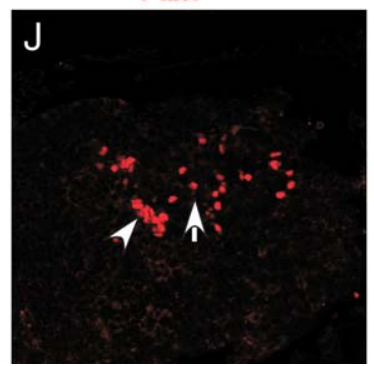

Glucagon

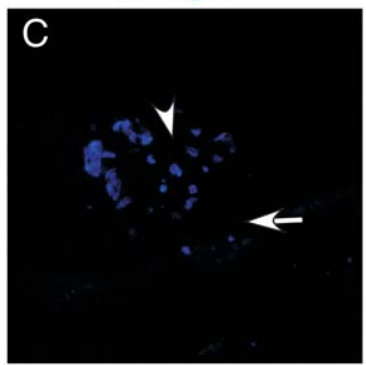

Glucagon

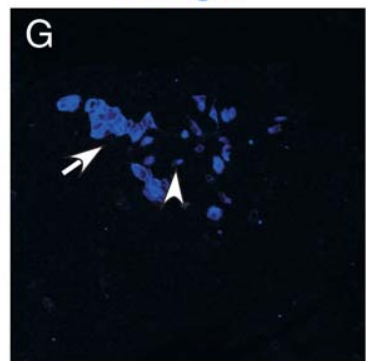

Glucagon

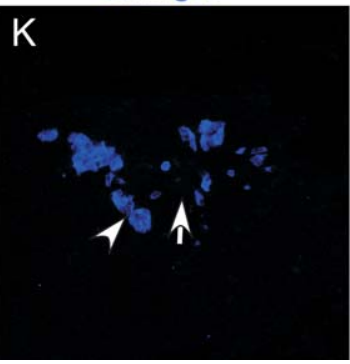

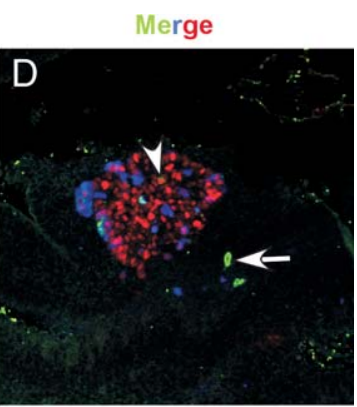

Merge

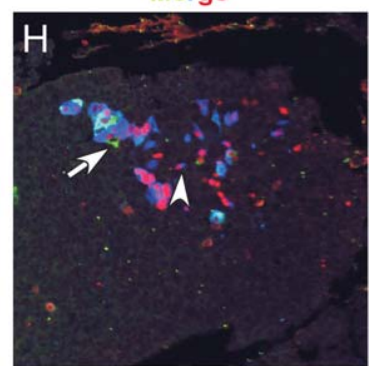

Merge

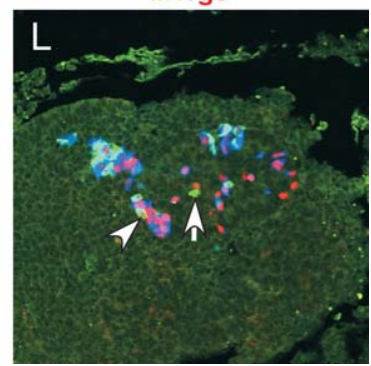

Figure $\mathbf{5}$

Expression of homeodomain transcription factors Pax6, Nkx2.2 and Brn4 in pancreatic ghrelin ${ }^{+}$cells at E15.5. Single panels for the triple stainings are presented along with a merge for all transcription factors. (A, B, C and D) Pax6 is expressed in ghrelin ${ }^{+}$glucagon ${ }^{+}$double immunoreactive $\alpha$-cells but not in ghrelin ${ }^{+}$glucagon ${ }^{-} \varepsilon$-cells $(E, F, G$ and $H$ ) Variable expression of Nkx2.2 is observed independent of whether the cells

around birth. Forty days after birth ghrelin cells are only occasionally seen, and in adult rat islets ghrelin cells are very rare. Similar to human ghrelin cells (Wierup et al. $2002,2004 b$ ), the rat pancreatic ghrelin cells precede the gastric ghrelin cells during pre- and postnatal development. Furthermore, the decrease in pancreatic ghrelin cell density is matched in time by an increase in gastric ghrelin cell density, indicating an inverse relationship between the two cell populations (Wierup et al. 2004b). This concept was supported by Chanoine \& Wong (2004) and Chanoine et al. (2006), who showed that the ghrelin gene expression and ghrelin peptide content in the foetal pancreas are markedly higher than that in the foetal stomach of rats. Thus the pancreas could be the main source of circulating ghrelin during late prenatal and early coexpress glucagon or not. (I, J, K and L) Bnr4 immunoreactivity is observed only in ghrelin cells immunoreactive for glucagon. Arrows point to examples of ghrelin single positive cells and arrowheads designate examples of cell coexpressing ghrelin and the indicated marker. For antibody details see Heller et al. (2005). All images are $400 \times$ magnification.

postnatal development when the gastric ghrelin cell density is still low. This pattern is reminiscent of gastrinproducing G-cells in rats, which are present in the pancreatic islets well before birth, but in the stomach only postnatally (Larsson et al. 1976a). Furthermore, although the number of gastric ghrelin cells is maintained at lower level by delayed weaning of rat pups, the islet ghrelin cell population is unaffected (Fak et al. 2007). The importance of this potential difference between the two cell populations in response to different nutrients needs further investigation. Very little is known about the developmental regulation of ghrelin cells in the rat. The data obtained so far indicate that rat ghrelin cells do not at any stage of development express insulin, PDX1 or somatostatin. On the other hand, occasional cells

Published by Bioscientifica Ltd. 
( $<1 \%$ of all ghrelin cells) express glucagon during a period around birth (Wierup et al. 2004b, Walia et al. 2008). Occasionally ghrelin cells also coexpress PP (Wierup et al. 2004b) (such cells are more common than those coexpressing ghrelin and glucagon) during a period around birth. This is indicating a developmental relationship between ghrelin cells, $\alpha$-cells and PP-cells. In addition, a subpopulation of the ghrelin cells harbour Brn4, a proposed $\alpha$-cell specific transcription factor (Hussain et al. 1997), further emphasising a lineage relationship between the $\alpha$-cells and the ghrelin cells. All ghrelin cells are devoid of glucagon and PP at later stages of development than postnatal day 5. Interestingly, the ghrelin cells are consistently devoid of CART peptide immunoreactivity (Wierup et al. 2004a, Wierup \& Sundler 2006). In this respect, the ghrelin cell differs from $\alpha-, \beta$-, $\delta$ - and PP-cells, which all to a varying extent express CART during foetal and neonatal development. The importance of this observation needs further investigation. It is, however, intriguing in view of the fact that all the CART-containing cell types remain to adulthood, while the ghrelin cells virtually disappear within weeks of birth. The observation that some ghrelin cells express cytokeratin 20, a marker of duct cells and islet precursor cells, indicates that the ghrelin cells originate from ductal epithelium, an acknowledged origin for islet cells in general (Bouwens et al. 1994). Some ghrelin cells also stain positive for proliferation markers, indicating that the ghrelin cells proliferate at a mature state. Hence, rat ghrelin cells seem to be generated both by duct cell differentiation and by cell replication. Further, Wang et al. reported that a great proportion of the ghrelin ${ }^{+}$glucagon ${ }^{+}$cells in mice also expressed IAPP to a high extent; this is different from the rat where IAPP expression in ghrelin cells is a rare phenomenon (Wierup et al. 2004b).

\section{Ghrelin cells in islets of other species}

The phylogeny of the ghrelin cells has not been thoroughly examined so far. Important pieces to the puzzle have, however, been added recently. Vedtofte $e t$ al (2007) reported that the islets of the desert gerbil (Psammomys obesus) also harbour ghrelin cells during development. The desert gerbil is closely related to the mouse and the data are largely in line with previous studies in mice (Prado et al. 2004, Heller et al. 2005). The same group reported, in accordance with adult mice and rats, that the islets of adult African ice rat (Otomys slogetti robertsi) are lacking ghrelin cells (Gustavsen et al. 2008). We have been unable to detect ghrelin cells in the islets of adult pigs, cats, dogs and guinea-pigs (Wierup $\mathrm{N} \&$ Sundler F, 2004, unpublished observations). Very recently ghrelin-immunoreactive cells have been found in the developing pancreas, but not in the adult pancreas, of the tammar wallaby (Macropus eugenii) (Menzies et al. 2008). We found ghrelin-immunoreactive cells in the pancreas of the Xenopous frog, while ghrelin cells are few in the pancreas of chickens (Wierup N \& Sundler F, 2004, unpublished observations). Importantly, ghrelin mRNA is expressed in pancreas of cat fish (Kaiya et al. 2005) and ghrelin cells have been found in the zebrafish (Pauls et al. 2007). Thus, although it is clear that the ghrelin cell is highly evolutionarily conserved, further studies are needed to elucidate the phylogeny for the ghrelin cell.

\section{Ghrelin expression in other islet cell types?}

A few reports have shown ghrelin immunoreactivity in other islet cells than the ghrelin cells of adult humans or rodents. Thus, Volante et al. (2002) showed ghrelin immunoreactivity in human $\beta$-cells, while Date et al. (2002) showed ghrelin immunoreactivity in human $\alpha$-cells. Date et al. (2002) also showed ghrelin immunoreactivity in the $\alpha$-cells of rats. We could not confirm any of these observations. Importantly, our ISH for ghrelin mRNA do not show any expression of ghrelin mRNA in $\alpha$ - or $\beta$-cells (Wierup et al. 2002, 2004b). The reason for this discrepancy still remains to be elucidated. Although some reports show undetectable (Chanoine \& Wong 2004, Wierup et al. 2004b, Walia et al. 2008) and others only very low (Dornonville de la Cour et al. 2001, Chanoine et al. 2006) levels of ghrelin in adult rat pancreas, it cannot be excluded that cell types other than ghrelin cells express ghrelin at very low levels, e.g. below the detection level of immunocytochemistry. Another possible explanation for detectable levels of ghrelin in the extracts of adult rat pancreas, which is devoid of islet ghrelin cells, could be the presence of ghrelin cells in association with pancreatic ducts (Wierup N \& Sundler F, 2004, unpublished observations).

\section{Ghrelin and islet hormone secretion}

A body of evidence shows that ghrelin is an insulinostatic agent, and that GHS-R is expressed in $\beta$-cells (Wierup et al. 2004b, Dezaki et al. 2008). Thus, ghrelin inhibits insulin release in humans, rats, mice, as well as from clonal $\beta$-cells (Broglio et al. 2001, 2003, Egido et al. 2002, Colombo et al. 2003, Reimer et al. 2003, Wierup et al. 2004b). These data indicate that ghrelin released from ghrelin cells within the islets could act as a paracrine inhibitor of insulin secretion.

Published by Bioscientifica Ltd 
Although reports showing that ghrelin inhibits insulin secretion predominate, it should be mentioned that a few reports have shown stimulatory effects (Date et al. 2002, Lee et al. 2002, van der Lely et al. 2004, Salehi et al. 2004, Cummings et al. 2005). The divergent data may reflect species differences or differences in methodology, such as ghrelin and glucose concentrations and time of observation, in vitro vs in vivo experiments, etc. Illustrating this complexity, Salehi et al. demonstrated a dose-dependent, biphasic action of ghrelin on GSIS from isolated mouse islets. Thus, in low concentrations ghrelin suppressed insulin secretion while in high concentrations ghrelin increased insulin secretion (Salehi et al. 2004). Another fact that has to be accounted for is the constitutive, i.e. ligand-independent receptor activity of GHS-R (Holst et al. 2003). This is an intriguing finding that needs further investigation in the context of the physiological regulation of insulin release caused by ghrelin. From a physiological point of view, it seems reasonable that the inhibitory effect is the most likely. The fact that ghrelin is increased by fasting (a state with a low need for insulin) and suppressed post-prandially (Tschop et al. 2000, Dornonville de la Cour et al. 2001, Toshinai et al. 2001) (a state of high insulin demand), together with the documented reciprocal relationship between ghrelin and insulin in plasma (Korbonits et al. 2004, Dezaki et al. 2008), do not favour a role for ghrelin as a stimulator of insulin secretion. It is tempting to hypothesise that the role for ghrelin is to prevent hypoglycaemia by suppressing inappropriate insulin secretion between meals. The effect of ghrelin on islet hormones other than insulin is less studied. One report showed inhibitory effects of ghrelin on somatostatin secretion, while no effects were seen on glucagon secretion from perfused rat pancreas (Egido et al. 2002). On the other hand, a stimulatory effect of ghrelin on glucagon secretion was observed on isolated islets but not in intact mice (Salehi et al. 2004). Another report showed a stimulatory effect of ghrelin on both somatostatin and PP-secretion in humans (Arosio et al. 2003). Taken together, ghrelin is an insulinostatic hormone, and a role for ghrelin regulation of glucagon, somatostatin and PP seems likely, although the exact function needs further investigation.

\section{Clinical importance of islet ghrelin}

The importance of the finding of a new human cell type, secreting a novel hormone at a novel site is hard to overestimate. Ghrelin cells are present in most islets in the human adult pancreas. On average three to five ghrelin cells are found in each islet. The human pancreas harbours approximately one million islets. Hence between three and five million ghrelin cells are present in each adult human pancreas. In humans $35-45 \%$ of the circulating ghrelin remains when the stomach, which is regarded as the dominating site of ghrelin production, is surgically removed (Ariyasu et al. 2001, Popovic et al. 2005). It is highly likely that the islet ghrelin cells together substantially contribute to a substantial part of the remaining circulating ghrelin.

A body of evidence has shown that ghrelin inhibits insulin secretion (Dezaki et al. 2008). Therefore blocking of ghrelin signalling is a novel strategy for the treatment for type 2 diabetes. Interestingly, therefore, oral administration of a GHS-R antagonist improved glucose homeostasis in rodents (Esler et al. 2007). In combination with the appetite stimulatory effects of ghrelin, the potential for such agents to treat also obesity is intriguing and needs further investigation (Dezaki et al. 2008).

Ghrelin cells appear as a separate cell type distinct from $\alpha_{-}, \beta-, \delta-$ and PP-cells when culturing human embryonic stem cells (D'Amour et al. 2006, Kroon et al. 2008). Hence, developmental studies and studies aimed at engineering new $\beta$-cells from human embryonic stem cells for transplantation to cure type 1 diabetes should benefit from increased knowledge about the different terminal fates of the islets cell types.

Several reports of pancreatic tumors with ghrelin expression (Rindi et al. 2002b, Volante et al. 2002, Leontiou et al. 2007) suggest that ghrelin could be a potential tumour marker to search for in the blood samples, although one report was unable to detect differences in plasma ghrelin between patients with ghrelin-expressing tumours and controls (Corbetta et al. 2003), it has been suggested that patients with malignant gastric endocrine tumours should be investigated for ghrelin production (Tsolakis et al. 2004). The potential for ghrelin as a novel tool for detecting previously silent tumours is intriguing and needs further investigation.

\section{Concluding remarks}

The ghrelin cell is a novel islet cell type in humans, rats, mice and fish. The ghrelin cell is thus highly conserved during evolution. Man is the only species so far known to have substantial numbers of ghrelin cells in the islets as adults. This makes studies of ghrelin cells and their role in the pancreas of adults difficult, because there are no known animal models with ghrelin cells in adults. The information gained on developing animals must be

Published by Bioscientifica Ltd. 
interpreted with caution as they poorly reflect the situation in man. Important information about the regulation of ghrelin cell development has been presented recently, but the transcriptional events that determine ghrelin cell fate need further investigation. Ghrelin secreted from ghrelin cells within the islets could act as a paracrine inhibitor of insulin secretion, and blockade of ghrelin signalling could be a therapeutic strategy for type 2 diabetes.

\section{Declaration of interest}

The authors declare that there is no conflict of interest that could be perceived as prejudicing the impartiality of the review.

\section{Funding}

Grants support from Swedish Medical Research Council (Projects No. 522-2008-4216, K2007-55X-04499-33-3), The Novo Nordisk Foundation, The Royal Physiographic Society in Lund, The Gyllenstiernska Krapperup, The Tore Nilsson, Åke Wiberg, Lars Hierta, Fredrik and Ingrid Thuring, Magnus Bergwall, Albert Påhlsson, Åhlén and The Swedish Society of Medicine Foundations. Expert technical assistance was provided by Doris Persson and Britt-Marie Nilsson.

\section{References}

Alumets J, Sundler F \& Hakanson R 1977 Distribution, ontogeny and ultrastructure of somatostatin immunoreactive cells in the pancreas and gut. Cell and Tissue Research 185 465-479. (doi:10.1007/ BF00220651)

Alumets J, Hakanson R \& Sundler F 1983 Ontogeny of endocrine cells in porcine gut and pancreas. An immunocytochemical study. Gastroenterology 85 1359-1372.

Ariyasu H, Takaya K, Tagami T, Ogawa Y, Hosoda K, Akamizu T, Suda M, Koh T, Natsui K, Toyooka S et al. 2001 Stomach is a major source of circulating ghrelin, and feeding state determines plasma ghrelin-like immunoreactivity levels in humans. Journal of Clinical Endocrinology and Metabolism 86 4753-4758. (doi:10.1210/jc.86.10.4753)

Arnes L, Hill JT, Gross S, Magnuson MA \& Sussel L 2012 Ghrelin expression in the mouse pancreas defines a unique multipotent progenitor population. PLOS ONE 7 e52026. (doi:10.1371/journal.pone.0052026)

Arosio M, Ronchi CL, Gebbia C, Cappiello V, Beck-Peccoz P \& Peracchi M 2003 Stimulatory effects of ghrelin on circulating somatostatin and pancreatic polypeptide levels. Journal of Clinical Endocrinology and Metabolism 88 701-704. (doi:10.1210/jc.2002-021161)

Banting FG \& Best CH 1922 The internal secretion of the pancreas. Journal of Laboratory and Clinical Medicine VII 256-271.

Baum J, Simons BE Jr, Unger RH \& Madison LL 1962 Localization of glucagon in the $\alpha$ cells in the pancreatic islet by immunofluorescent technics. Diabetes 11 371-374.

Bencosme SA \& Liepa E 1955 Regional differences of the pancreatic islet. Endocrinology 57 588-593. (doi:10.1210/endo-57-5-588)

Bencosme SA, Liepa E \& Lazarus SS 1955 Glucagon content of pancreatic tissue devoid of $\alpha$ cells. Proceedings of the Society for Experimental Biology and Medicine 90 387-392. (doi:10.3181/00379727-90-22042)

Biedl A 1913 Innere Sekretion. Ihre Physiologischen Grundlagen und Ihre Bedeutung für die Pathologie. Berlin, Germany: Urban \& Schwarzenberg.

Bloom W 1931 A new type of granular cell in the islets of Langerhans of man. Anatomical Record 49 363-371. (doi:10.1002/ar.1090490406)
Bordi C, Ferrari C, D'Adda T, Pilato F, Carfagna G, Bertele A \& Missale G 1986 Ultrastructural characterization of fundic endocrine cell hyperplasia associated with atrophic gastritis and hypergastrinaemia. Virchows Archiv. A, Pathological Anatomy and Histopathology 409 335-347. (doi:10.1007/BF00708251)

Bouwens L, Wang RN, De Blay E, Pipeleers DG \& Kloppel G 1994 Cytokeratins as markers of ductal cell differentiation and islet neogenesis in the neonatal rat pancreas. Diabetes 43 1279-1283. (doi:10.2337/diab.43.11.1279)

Broglio F, Arvat E, Benso A, Gottero C, Muccioli G, Papotti M, Lely AJ, Deghenghi R \& Ghigo E 2001 Ghrelin, a natural GH secretagogue produced by the stomach, induces hyperglycemia and reduces insulin secretion in humans. Journal of Clinical Endocrinology and Metabolism 86 5083. (doi:10.1210/jc.86.10.5083)

Broglio F, Gottero C, Benso A, Prodam F, Destefanis S, Gauna C, Maccario M, Deghenghi R, van der Lely AJ \& Ghigo E 2003 Effects of ghrelin on the insulin and glycemic responses to glucose, arginine, or free fatty acids load in humans. Journal of Clinical Endocrinology and Metabolism $\mathbf{8 8}$ 4268-4272. (doi:10.1210/jc.2002-021940)

Capella C, Hage E, Solcia E \& Usellini L 1978 Ultrastructural similarity of endocrine-like cells of the human lung and some related cells of the gut. Cell and Tissue Research 186 25-37. (doi:10.1007/BF00219652)

Chanoine JP \& Wong AC 2004 Ghrelin gene expression is markedly higher in fetal pancreas compared to fetal stomach: effect of maternal fasting. Endocrinology 145 3813-3820. (doi:10.1210/en.2004-0053)

Chanoine JP, Wong AC \& Barrios V 2006 Obestatin, acylated and total ghrelin concentrations in the perinatal rat pancreas. Hormone Research 66 81-88. (doi:10.1159/000093585)

Collombat P, Mansouri A, Hecksher-Sorensen J, Serup P, Krull J, Gradwohl G \& Gruss P 2003 Opposing actions of Arx and Pax4 in endocrine pancreas development. Genes and Development 17 2591-2603. (doi:10.1101/gad.269003)

Colombo M, Gregersen S, Xiao J \& Hermansen K 2003 Effects of ghrelin and other neuropeptides (CART, MCH, Orexin A and B, and GLP-1) on the release of insulin from isolated rat islets. Pancreas 27 161-166. (doi:10.1097/00006676-200308000-00009)

Corbetta S, Peracchi M, Cappiello V, Lania A, Lauri E, Vago L, Beck-Peccoz P \& Spada A 2003 Circulating ghrelin levels in patients with pancreatic and gastrointestinal neuroendocrine tumors: identification of one pancreatic ghrelinoma. Journal of Clinical Endocrinology and Metabolism 88 3117-3120. (doi:10.1210/jc.2002-021842)

Cortelazzi D, Cappiello V, Morpurgo PS, Ronzoni S, Nobile De Santis MS, Cetin I, Beck-Peccoz P \& Spada A 2003 Circulating levels of ghrelin in human fetuses. European Journal of Endocrinology 149 111-116. (doi:10.1530/eje.0.1490111)

Cummings DE, Foster-Schubert KE \& Overduin J 2005 Ghrelin and energy balance: focus on current controversies. Current Drug Targets 6 153-169. (doi:10.2174/1389450053174569)

D'Amour KA, Bang AG, Eliazer S, Kelly OG, Agulnick AD, Smart NG, Moorman MA, Kroon E, Carpenter MK \& Baetge EE 2006 Production of pancreatic hormone-expressing endocrine cells from human embryonic stem cells. Nature Biotechnology 24 1392-1401. (doi:10.1038/ nbt1259)

Date Y, Kojima M, Hosoda H, Sawaguchi A, Mondal MS, Suganuma T, Matsukura S, Kangawa K \& Nakazato M 2000 Ghrelin, a novel growth hormone-releasing acylated peptide, is synthesized in a distinct endocrine cell type in the gastrointestinal tracts of rats and humans. Endocrinology 141 4255-4261. (doi:10.1210/en.141.11.4255)

Date Y, Nakazato M, Hashiguchi S, Dezaki K, Mondal MS, Hosoda H, Kojima M, Kangawa K, Arima T, Matsuo H et al. 2002 Ghrelin is present in pancreatic $\alpha$-cells of humans and rats and stimulates insulin secretion. Diabetes 51 124-129. (doi:10.2337/diabetes.51.1.124)

Dezaki K, Sone H \& Yada T 2008 Ghrelin is a physiological regulator of insulin release in pancreatic islets and glucose homeostasis. Pharmacology \& Therapeutics 118 239-249. (doi:10.1016/j.pharmthera. 2008.02.008) http://jme.endocrinology-journals.org

DOI: 10.1530/JME-13-0122
() 2014 Society for Endocrinology Printed in Great Britain 
Dornonville de la Cour C, Bjorkqvist M, Sandvik AK, Bakke I, Zhao CM, Chen D \& Hakanson R 2001 A-like cells in the rat stomach contain ghrelin and do not operate under gastrin control. Regulatory Peptides 99 141-150. (doi:10.1016/S0167-0115(01)00243-9)

Edlund H 2002 Pancreatic organogenesis - developmental mechanisms and implications for therapy. Nature Reviews. Genetics 3 524-532. (doi:10.1038/nrg841)

Egido EM, Rodriguez-Gallardo J, Silvestre RA \& Marco J 2002 Inhibitory effect of ghrelin on insulin and pancreatic somatostatin secretion. European Journal of Endocrinology 146 241-244. (doi:10.1530/ eje.0.1460241)

Ekblad E \& Sundler F 2002 Distribution of pancreatic polypeptide and peptide YY. Peptides 23 251-261. (doi:10.1016/S0196-9781(01)00601-5)

Esler WP, Rudolph J, Claus TH, Tang W, Barucci N, Brown SE, Bullock W, Daly M, Decarr L, Li Y et al. 2007 Small-molecule ghrelin receptor antagonists improve glucose tolerance, suppress appetite, and promote weight loss. Endocrinology 148 5175-5185. (doi:10.1210/en.2007-0239)

Fak F, Friis-Hansen L, Westrom B \& Wierup N 2007 Gastric ghrelin cell development is hampered and plasma ghrelin is reduced by delayed weaning in rats. Journal of Endocrinology 192 345-352. (doi:10.1677/ joe.1.07077)

Falkmer S 1995 Origin of the parenchymal cells of the endocrine pancreas: some phylogenetic and ontogenetic aspects. In Endocrine Tumours of the Pancreas, pp 2-29. Eds M Mignon \& RT Jensen. Basel, Switzerland: S. Karger.

Fujita T 1968 D cell, the third endocrine element of the pancreatic islet. Archivum Histologicum Japonicum 29 1-40. (doi:10.1679/aohc1950.29.1)

Gradwohl G, Dierich A, LeMeur M \& Guillemot F 2000 neurogenin3 is required for the development of the four endocrine cell lineages of the pancreas. PNAS 97 1607-1611. (doi:10.1073/pnas.97.4.1607)

Grimelius L 1968 A silver nitrate stain for $\alpha-2$ cells in human pancreatic islets. Acta Societatis Medicorum Upsaliensis 73 243-270.

Gustavsen CR, Pillay N \& Heller RS 2008 An immunohistochemical study of the endocrine pancreas of the African ice rat, Otomys sloggetti robertsi. Acta Histochemica 110 294-301. (doi:10.1016/j.acthis.2007.11.003)

Heller RS, Stoffers DA, Liu A, Schedl A, Crenshaw EB III, Madsen OD \& Serup P 2004 The role of Brn4/Pou3f4 and Pax6 in forming the pancreatic glucagon cell identity. Developmental Biology 268 123-134. (doi:10.1016/j.ydbio.2003.12.008)

Heller RS, Jenny M, Collombat P, Mansouri A, Tomasetto C, Madsen OD, Mellitzer G, Gradwohl G \& Serup P 2005 Genetic determinants of pancreatic epsilon-cell development. Developmental Biology 286 217-224. (doi:10.1016/j.ydbio.2005.06.041)

Hellerström C \& Hellman B 1960 Some aspects of silver impregnation of the islets of Langerhans in the rat. Acta Endocrinologica 35 518-532.

Hellerström C \& Hellman B 1962 Reactions of the two types of A cells in the islets of Langerhans after administration of glucagon. Acta Endocrinologica 41 116-122.

Hellman B, Wallgren A \& Hellerstrom C 1962 Two types of islet $\alpha$ cells in different parts of the pancreas of the dog. Nature 194 1201-1202. (doi:10.1038/1941201a0)

Hokfelt T, Efendic S, Hellerstrom C, Johansson O, Luft R \& Arimura A 1975 Cellular localization of somatostatin in endocrine-like cells and neurons of the rat with special references to the A1-cells of the pancreatic islets and to the hypothalamus. Acta Endocrinologica. Supplementum 200 5-41.

Holst B, Cygankiewicz A, Jensen TH, Ankersen M \& Schwartz TW 2003 High constitutive signaling of the ghrelin receptor - identification of a potent inverse agonist. Molecular Endocrinology 17 2201-2210. (doi:10.1210/me.2003-0069)

Howard AD, Feighner SD, Cully DF, Arena JP, Liberator PA, Rosenblum CI, Hamelin M, Hreniuk DL, Palyha OC, Anderson J et al. 1996 A receptor in pituitary and hypothalamus that functions in growth hormone release. Science 273 974-977. (doi:10.1126/science.273.5277.974)

Hussain MA, Lee J, Miller CP \& Habener JF 1997 POU domain transcription factor brain 4 confers pancreatic $\alpha$-cell-specific expression of the proglucagon gene through interaction with a novel proximal promoter G1 element. Molecular and Cellular Biology 17 7186-7194.

Jenny M, Heller RS, Collombat P, Mansouri A, Scedl A, Tomasetto C, Madsen OD, Gradwohl G \& Serup P 2004 Pancreatic ghrelin cell population depends on neurogenin 3. In REGPEP 2004, p A69. Toulouse, France: Regul Pept.

Jirasek K \& Kubes L 1972 A new endocrine cell type of the human pancreatic islets. Experientia 28 966-967. (doi:10.1007/BF01924976)

Kaiya H, Small BC, Bilodeau AL, Shepherd BS, Kojima M, Hosoda H \& Kangawa K 2005 Purification, cDNA cloning, and characterization of ghrelin in channel catfish, Ictalurus punctatus. General and Comparative Endocrinology 143 201-210. (doi:10.1016/j.ygcen.2005. 03.012)

Klöppel G \& Heitz PU 1984 Nesidioblastosis: a clinical entity with heterogeneous lesions of the pancreas. In Evolution and Tumour Pathology of the Neuroendocrine System, pp 349-370. Eds S Falkmer, R Håkanson \& F Sundler. Amsterdam, The Netherlands: Elsevier.

Kojima M, Hosoda H, Date Y, Nakazato M, Matsuo H \& Kangawa K 1999 Ghrelin is a growth-hormone-releasing acylated peptide from stomach. Nature 402 656-660. (doi:10.1038/45230)

Korbonits M, Goldstone AP, Gueorguiev M \& Grossman AB 2004 Ghrelin a hormone with multiple functions. Frontiers in Neuroendocrinology $\mathbf{2 5}$ 27-68. (doi:10.1016/j.yfrne.2004.03.002)

Kroon E, Martinson LA, Kadoya K, Bang AG, Kelly OG, Eliazer S, Young H, Richardson M, Smart NG, Cunningham J et al. 2008 Pancreatic endoderm derived from human embryonic stem cells generates glucose-responsive insulin-secreting cells in vivo. Nature Biotechnology 26 443-452. (doi:10.1038/nbt1393)

Lacy PE 1957 Electron microscopy of the normal islets of Langerhans; studies in the dog, rabbit, guinea pig and rat. Diabetes 6 498-507.

Lacy PE \& Davies J 1957 Preliminary studies on the demonstration of insulin in the islets by the fluorescent antibody technic. Diabetes $\mathbf{6}$ 354-357.

Laguesse E 1893 Sur la formation des flots de Langerhans dans le pancreas. Comptes Rendus des Seances de la Societe de Biologie et des ses Filiales 14 819-820.

Lane MA 1907 The cytological characters of the areas of Langerhans. American Journal of Anatomy 7 409-422. (doi:10.1002/aja.1000070304)

Langerhans P 1869 Contributions to the microscopic anatomy of the pancreas. In Faculty of Medicine. Berlin, Germany: University of Berlin.

Larsson LI, Sundler F, Hakanson R, Pollock HG \& Kimmel JR 1974 Localization of APP, a postulated new hormone, to a pancreatic endocrine cell type. Histochemistry 42 377-382. (doi:10.1007/ BF00492685)

Larsson LI, Sundler F \& Hakanson R 1975 Immunohistochemical localization of human pancreatic polypeptide (HPP) to a population of islet cells. Cell and Tissue Research 156 167-171. (doi:10.1007/ BF00221800)

Larsson LI, Rehfeld JF, Sundler F \& Hakanson R 1976a Pancreatic gastrin in foetal and neonatal rats. Nature 262 609-610. (doi:10.1038/262609a0)

Larsson LI, Sundler F \& Hakanson R 1976b Pancreatic polypeptide - a postulated new hormone: identification of its cellular storage site by light and electron microscopic immunocytochemistry. Diabetologia 12 211-226. (doi:10.1007/BF00422088)

Lee HM, Wang G, Englander EW, Kojima M \& Greeley GH Jr 2002 Ghrelin, a new gastrointestinal endocrine peptide that stimulates insulin secretion: enteric distribution, ontogeny, influence of endocrine, and dietary manipulations. Endocrinology 143 185-190. (doi:10.1210/en.143.1.185)

Lee CS, Sund NJ, Behr R, Herrera PL \& Kaestner KH 2005 Foxa2 is required for the differentiation of pancreatic $\alpha$-cells. Developmental Biology 278 484-495. (doi:10.1016/j.ydbio.2004.10.012)

van der Lely AJ, Tschop M, Heiman ML \& Ghigo E 2004 Biological, physiological, pathophysiological, and pharmacological aspects of ghrelin. Endocrine Reviews 25 426-457. (doi:10.1210/er.2002-0029) http://jme.endocrinology-journals.org

DOI: 10.1530/JME-13-0122 (c) 2014 Society for Endocrinology Printed in Great Britain 
Leontiou CA, Franchi G \& Korbonits M 2007 Ghrelin in neuroendocrine organs and tumours. Pituitary 10 213-225. (doi:10.1007/s11102-0070023-0)

Like AA 1967 The ultrastructure of the secretory cells of the islets of Langerhans in man. Laboratory Investigation 16 937-951.

Mastracci TL, Wilcox CL, Arnes L, Panea C, Golden JA, May CL \& Sussel L $2011 \mathrm{Nkx} 2.2$ and Arx genetically interact to regulate pancreatic endocrine cell development and endocrine hormone expression. Developmental Biology 359 1-11. (doi:10.1016/j.ydbio.2011.08.001)

Mazur MA, Winkler M, Ganic E, Colberg JK, Johansson JK, Bennet H, Fex M, Nuber UA \& Artner I 2013 Microphthalmia transcription factor regulates pancreatic $\beta$-cell function. Diabetes 62 2834-2842. (doi:10.2337/db12-1464)

Menzies BR, Shaw G, Fletcher TP \& Renfree MB 2009 Early onset of ghrelin production in a marsupial. Molecular and Cellular Endocrinology 299 266-273. (doi:10.1016/j.mce.2008.10.033)

Mikami SI \& Ono K 1962 Glucagon deficiency induced by extirpation of $\alpha$ islets of the fowl pancreas. Endocrinology 71 464-473. (doi:10.1210/ endo-71-3-464)

Oliver-Krasinski JM \& Stoffers DA 2008 On the origin of the $\beta$ cell. Genes and Development 22 1998-2021. (doi:10.1101/gad.1670808)

Orci L, Baetens D, Dubois MP \& Rufener C 1975 Evidence for the D-cell of the pancreas secreting somatostatin. Hormone and Metabolic Research 7 400-402. (doi:10.1055/s-0028-1093736)

Papizan JB, Singer RA, Tschen SI, Dhawan S, Friel JM, Hipkens SB, Magnuson MA, Bhushan A \& Sussel L 2011 Nkx2.2 repressor complex regulates islet $\beta$-cell specification and prevents $\beta$-to- $\alpha$-cell reprogramming. Genes and Development 25 2291-2305. (doi:10.1101/gad. 173039.111)

Pauls S, Zecchin E, Tiso N, Bortolussi M \& Argenton F 2007 Function and regulation of zebrafish nkx2.2a during development of pancreatic islet and ducts. Developmental Biology 304 875-890. (doi:10.1016/j.ydbio. 2007.01.024)

Peeters TL 2005 Ghrelin: a new player in the control of gastrointestinal functions. Gut 54 1638-1649. (doi:10.1136/gut.2004.062604)

Polak JM, Pearse AG, Grimelius L \& Bloom SR 1975 Growth-hormone release-inhibiting hormone in gastrointestinal and pancreatic D cells. Lancet 1 1220-1222. (doi:10.1016/S0140-6736(75)92198-4)

Popovic V, Miljic D, Pekic S, Pesko P, Djurovic M, Doknic M, Damjanovic S, Micic D, Cvijovic G, Glodic J et al. 2005 Low plasma ghrelin level in gastrectomized patients is accompanied by enhanced sensitivity to the ghrelin-induced growth hormone release. Journal of Clinical Endocrinology and Metabolism 90 2187-2191. (doi:10.1210/jc.2004-1888)

Prado CL, Pugh-Bernard AE, Elghazi L, Sosa-Pineda B \& Sussel L 2004 Ghrelin cells replace insulin-producing $\beta$ cells in two mouse models of pancreas development. PNAS 101 2924-2929. (doi:10.1073/pnas. 0308604100)

Reimer MK, Pacini G \& Ahren B 2003 Dose-dependent inhibition by ghrelin of insulin secretion in the mouse. Endocrinology 144 916-921. (doi:10.1210/en.2002-220819)

Rindi G, Necchi V, Savio A, Torsello A, Zoli M, Locatelli V, Raimondo F, Cocchi D \& Solcia E 2002a Characterisation of gastric ghrelin cells in man and other mammals: studies in adult and fetal tissues. Histochemistry and Cell Biology 117 511-519. (doi:10.1007) s00418-002-0415-1)

Rindi G, Savio A, Torsello A, Zoli M, Locatelli V, Cocchi D, Paolotti D \& Solcia E $2002 b$ Ghrelin expression in gut endocrine growths. Histochemistry and Cell Biology 117 521-525. (doi:10.1007/ s00418-002-0416-0)

Rudnick A, Ling TY, Odagiri H, Rutter WJ \& German MS 1994 Pancreatic $\beta$ cells express a diverse set of homeobox genes. PNAS 91 12203-12207. (doi:10.1073/pnas.91.25.12203)

Salehi A, Dornonville de la Cour C, Hakanson R \& Lundquist I 2004 Effects of ghrelin on insulin and glucagon secretion: a study of isolated pancreatic islets and intact mice. Regulatory Peptides 118 143-150. (doi:10.1016/j.regpep.2003.12.001)
Samols E 1991 The history of the endocrine pancreas. In The Endocrine Pancreas, pp 1-14. Ed E Samols. New York: Raven Press.

Solcia E, Fiocca R, Capella C, Usellini L, Sessa F, Rindi G, Schwartz TW \& Yanaihara N 1985 Glucagon- and PP-related peptides of intestinal L cells and pancreatic/gastric A or PP cells. Possible interrelationships of peptides and cells during evolution, fetal development and tumor growth. Peptides 6 (Suppl 3) 223-229. (doi:10.1016/0196-9781(85) 90378-X)

Solcia E, Capella C, Buffa R, Usellini L, Fiocca R \& Sessa F 1987 Endocrine cells of the digestive system. In Physiology of the Gastrointestinal Tract, pp 111-130. Ed J L R New York: Raven Press.

Suissa Y, Magenheim J, Stolovich-Rain M, Hija A, Collombat P, Mansouri A, Sussel L, Sosa-Pineda B, McCracken K, Wells JM et al. 2013 Gastrin: a distinct fate of neurogenin 3 positive progenitor cells in the embryonic pancreas. PLOS ONE 8 e70397. (doi:10.1371/journal. pone.0070397)

Sundler F \& Håkanson R 1988 Peptide hormone-producing endocrine/ paracrine cells in the gastro-entero-pancreatic region. In Handbook of Chemical Neuroanatomy, pp 219-295. Eds A Björklund, T Hökfelt \& C Owman: Elsevier Science Publishers.

Sussel L, Kalamaras J, Hartigan-O'Connor DJ, Meneses JJ, Pedersen RA, Rubenstein JL \& German MS 1998 Mice lacking the homeodomain transcription factor Nkx2.2 have diabetes due to arrested differentiation of pancreatic $\beta$ cells. Development 125 2213-2221.

Tomasetto C, Karam SM, Ribieras S, Masson R, Lefebvre O, Staub A, Alexander G, Chenard MP \& Rio MC 2000 Identification and characterization of a novel gastric peptide hormone: the motilin-related peptide. Gastroenterology 119 395-405. (doi:10.1053/ gast.2000.9371)

Toshinai K, Mondal MS, Nakazato M, Date Y, Murakami N, Kojima M, Kangawa K \& Matsukura S 2001 Upregulation of ghrelin expression in the stomach upon fasting, insulin-induced hypoglycemia, and leptin administration. Biochemical and Biophysical Research Communications 281 1220-1225. (doi:10.1006/bbrc.2001.4518)

Tschop M, Smiley DL \& Heiman ML 2000 Ghrelin induces adiposity in rodents. Nature 407 908-913. (doi:10.1038/35038090)

Tsolakis AV, Portela-Gomes GM, Stridsberg M, Grimelius L, Sundin A, Eriksson BK, Oberg KE \& Janson ET 2004 Malignant gastric ghrelinoma with hyperghrelinemia. Journal of Clinical Endocrinology and Metabolism 89 3739-3744. (doi:10.1210/jc.2003-032118)

Vedtofte L, Bodvarsdottir TB, Karlsen AE \& Heller RS 2007 Developmental biology of the Psammomys obesus pancreas: cloning and expression of the neurogenin-3 gene. Journal of Histochemistry and Cytochemistry $\mathbf{5 5}$ 97-104. (doi:10.1369/jhc.6A7073.2006)

Volante M, Allia E, Gugliotta P, Funaro A, Broglio F, Deghenghi R, Muccioli G, Ghigo E \& Papotti M 2002 Expression of ghrelin and of the GH secretagogue receptor by pancreatic islet cells and related endocrine tumors. Journal of Clinical Endocrinology and Metabolism $\mathbf{8 7}$ 1300-1308. (doi:10.1210/jc.87.3.1300)

Walia P, Asadi A, Kieffer TJ, Johnson JD \& Chanoine JP 2009 Ontogeny of ghrelin, obestatin, preproghrelin, and prohormone convertases in rat pancreas and stomach. Pediatric Research 65 39-44. (doi:10.1203/PDR. 0b013e31818bc134)

Wang J, Elghazi L, Parker SE, Kizilocak H, Asano M, Sussel L \& Sosa-Pineda B 2004 The concerted activities of Pax4 and Nkx2.2 are essential to initiate pancreatic $\beta$-cell differentiation. Developmental Biology 266 178-189. (doi:10.1016/j.ydbio.2003.10.018)

Wang Q, Elghazi L, Martin S, Martins I, Srinivasan RS, Geng X, Sleeman M, Collombat P, Houghton J \& Sosa-Pineda B 2008 Ghrelin is a novel target of Pax4 in endocrine progenitors of the pancreas and duodenum. Developmental Dynamics 237 51-61. (doi:10.1002/dvdy.21379)

Wierup N 2005 Ghrelin and CART, two new islet peptides. Expression, regulation, and function. In Department of Experimental Medical Science, p 73. Lund, Sweden: Lund University.

Wierup N \& Sundler F 2004a Circulating levels of ghrelin in human fetuses. European Journal of Endocrinology 150 405. (doi:10.1530/eje.0.1500405) 
Wierup N \& Sundler F 2004b Human and murine pancreatic ghrelin cells. developmental aspects and ultrastructure. In REGPEP 2004, p A155. Toulouse, France: Regul pept.

Wierup N \& Sundler F 2005 Ultrastructure of islet ghrelin cells in the human fetus. Cell and Tissue Research 319 423-428. (doi:10.1007/ s00441-004-1044-x)

Wierup N \& Sundler F 2006 CART is a novel islet regulatory peptide. Peptides 27 2031-2036. (doi:10.1016/j.peptides.2006.02.011)

Wierup N \& Sundler F 2008 Neuropeptides-endocrine cells. In Encyclopedia of Neuroscience. Ed LR Squire. Oxford, UK: Academic Press.

Wierup N, Svensson H, Mulder H \& Sundler F 2002 The ghrelin cell: a novel developmentally regulated islet cell in the human pancreas. Regulatory Peptides 107 63-69. (doi:10.1016/S0167-0115(02)00067-8)
Wierup N, Kuhar M, Nilsson BO, Mulder H, Ekblad E \& Sundler F 2004a Cocaine- and amphetamine-regulated transcript (CART) is expressed in several islet cell types during rat development. Journal of Histochemistry and Cytochemistry 52 169-177. (doi:10.1177/002215540405200204)

Wierup N, Yang S, McEvilly RJ, Mulder H \& Sundler F 2004b Ghrelin is expressed in a novel endocrine cell type in developing rat islets and inhibits insulin secretion from INS-1 (832/13) cells. Journal of Histochemistry and Cytochemistry 52 301-310. (doi:10.1177/ $002215540405200301)$

Wierup N, Bjorkqvist M, Westrom B, Pierzynowski S, Sundler F \& Sjolund K 2007 Ghrelin and motilin are cosecreted from a prominent endocrine cell population in the small intestine. Journal of Clinical Endocrinology and Metabolism 92 3573-3581. (doi:10.1210/jc.2006-2756)

Received in final form 9 September 2013

Accepted 18 September 2013

Accepted Preprint published online 18 September 2013
(C) 2014 Society for Endocrinology Printed in Great Britain
Published by Bioscientifica Ltd. 